\title{
$\mathrm{Sn}-58 \mathrm{Bi}$ 솔더 페이스트와 ENIG 표면 처리된 기판 접합부의 계면 반응 및 접합강도
}

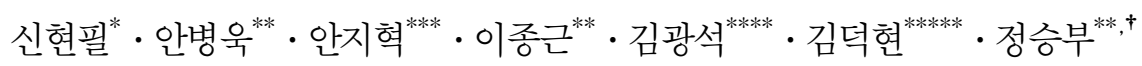 \\ *청솔화학환경 \\ **성균관대학교 신소재공학부 \\ ***한국기계연구원 부설 재료연구소 \\ ****성균관대학교 나노과학기술학부 \\ ***** 한국산업기술대학교
}

\section{Interfacial Reaction and Joint Strength of the Sn-58Bi Solder Paste with ENIG Surface Finished Substrate}

\author{
Hyun-Pil Shin*, Byung-Wook Ahn**, Jee-Hyuk Ahn***, Jong-Gun Lee**, Kwang-Seok Kim****, \\ Duk-Hyun Kim***** and Seung-Boo Jung**, $\dagger$ \\ *Chungsol C\&E CO,LTD, Gyeonggi-do 429-450, Korea \\ **School of Advanced Materials Science and Engineering, Sungkyunkwan University, \\ Suwon 440-746, Korea \\ ***Advanced Characteriazation and Analysis Department, Korea Institute of Materials Science, \\ Changwon 642-831, Korea \\ ****SKKU Advanced Institute of Nanotechnology (SAINT), Sungkyunkwan University, Suwon 440-746, Korea \\ *****Department of Chemcal Engineering \& Biotechnology, Korea Polytechnic University, \\ Siheung 429-793, Korea
}

†Corresponding author : sbjung@skku.edu

(Received October 8, 2012 ; Revised October 29, 2012 ; Accepted October 31, 2012)

\begin{abstract}
Sn-Bi eutectic alloy has been widely used as one of the key solder materials for step soldering at low temperature. The Sn-58Bi solder paste containing chloride flux was adopted to compare with that using the chloride-free flux. The paste was applied on the electroless nickel-immersion gold (ENIG) surface finish by stencil printing, and the reflow process was then performed at $170^{\circ} \mathrm{C}$ for $10 \mathrm{~min}$. After reflow, the solder joints were aged at $125^{\circ} \mathrm{C}$ for $100,200,300,500$ and $1000 \mathrm{~h}$ in an oven. The interfacial microstructures were obtained by using scanning electron microscopy (SEM), and the composition of intermetallic compounds (IMCs) was analyzed using energy dispersive spectrometer (EDS). Two different IMC layers, consisting of $\mathrm{Ni}_{3} \mathrm{Sn}_{4}$ and relatively very thin $\mathrm{Sn}-\mathrm{Bi}-\mathrm{Ni}$-Au were formed at the solder/surface finish interface, and their thickness increased with increasing aging time. The wettability of solder joints was investigated by wetting balance test. The mechanical property of each aging solder joint was evaluated by the ball shear test in accordance with JEDEC standard (JESD22-B117A). The results show that the highest shear force was measured when the aging time was $100 \mathrm{~h}$, and the fracture mode changed from ductile fracture to brittle fracture with increasing aging time. On the other hand, the chloride flux in the solder paste did not affect the shear force and fracture mode of the solder joints.
\end{abstract}

Key Words : Sn-58Bi solder paste, Wettability, Intermetallic compound (IMC), Aging, Shear test 


\section{1. 서 론}

최근 전자 패키지 기술은 전자제품의 소형화, 경량화 및 고성능화 추세에 따라 그 중요성이 점차 증대되고 있다. 더욱이 전 세계적으로 환경문제가 중요한 이슈로 제기되고 있기 때문에 $\mathrm{Sn}-\mathrm{Pb}$ 계 솔더를 대체 할 무연솔 더(lead-free solder)에 대한 연구가 활발하게 진행되 고 있으며, $\mathrm{Sn}-\mathrm{Ag}-\mathrm{Cu}$ 계 솔더와 $\mathrm{Sn}-\mathrm{Cu}$ 계 솔더가 현 재 많이 사용되고 있다. 현재 산업현장에서 많이 사용 되고 있는 $\mathrm{Sn}-3.0 \mathrm{Ag}-0.5 \mathrm{Cu}$ 조성의 솔더는 $217{ }^{\circ} \mathrm{C}$ 의 녹는점을 가지고 있지만 충분한 젖음성 및 솔더 반응 특성과 안정적인 솔더링 수율을 확보하기 위하여 $250{ }^{\circ} \mathrm{C}$ 이상의 피크 온도를 가지는 온도 프로파일을 적용해야 한다.

그러나 $250{ }^{\circ} \mathrm{C}$ 이상의 온도에서는 기판 재료의 열 화, 솔더 접합부에서의 과도한 금속간 화합물층 성장으 로 인해 기계적 신뢰성에 나쁜 영향을 줄 수 있기 때문 에 낮은 녹는점을 가진 저융점 솔더의 개발과 연구가 필요하다. $\mathrm{Sn}-58 \mathrm{Bi}$ 조성의 솔더는 $139{ }^{\circ} \mathrm{C}$ 의 비교적 낮은 융점을 가지기 때문에 $\mathrm{Sn}-\mathrm{Ag}-\mathrm{Cu}$ 계 솔더와 비교 할 때 낮은 공정 온도를 크게 낮출 수 있다. 또한 $\mathrm{Sn}-\mathrm{Bi}$ 조성의 솔더는 기존의 $\mathrm{Sn}-\mathrm{Pb}$ 조성의 솔더와 $\mathrm{Sn}-\mathrm{Ag}-\mathrm{Cu}$ 계 솔더보다 상대적으로 높은 강도값을 가진 다고 알려져 최근 활발하게 연구가 진행되고 있다.

하지만 상기 언급한 바와 같이 $\mathrm{Sn}-58 \mathrm{Bi}$ 솔더 합금 은 인장 시험 시 다른 솔더 합금에 비해 상대적으로 높 은 강도값을 나타내나, 탄성변형 범위 또는 작은 소성 변형에서 파단이 관찰되어 취성이 강한 것으로 보고되 고 있다. $\mathrm{Sn}-57 \mathrm{Bi}$ 솔더의 소성 변형량은 변형속도의 감소 조건에서 증가될 수 있는데, 즉, 솔더 조인트에 열팽창계수의 차이에 의한 일반적인 응력만이 작용하는 조건에서는 양호한 접합부 신뢰성을 나타낼 수 있으나, 낙하(drop)와 같은 급격한 충격이 솔더 조인트에 인가 될 경우에는 갑작스런 접합부의 파단을 야기시켜 낮은 낙하 신뢰성을 나타낼 수 있다. 아울러 $\mathrm{Sn}-\mathrm{Bi}$ 공정 조 성의 융점이 $139{ }^{\circ} \mathrm{C}$ 이므로 이 근방의 온도까지 승온되 는 조건에서의 솔더 접합부 신뢰성은 매우 급격하게 감 소하게 될 것임을 쉽게 예상할 수 있으므로, $\mathrm{Sn}-\mathrm{Bi}$ 솔 더의 신뢰성 분석은 매우 중요한 것으로 사료된다.

한편 지금까지 거론된 대표적인 전자패키징의 기계적 신뢰성 문제로는 패키지 열 변형에 의한 접합부의 층간 분리(package delamination), 솔더 조인트의 피로 파손(fatigue failure) 등이 있다. 이는 패키지에 물리 적인 충격을 주기 때문에 전자 소자의 전기적 기능 수
행에 큰 영향을 미치므로 전자 소자 자체의 신뢰성뿐만 아니라 다양한 패키지 방법에 따른 기계적 신뢰성 확보 가 요구된다. 전단시험(shear test)은 패키지의 기계적 신뢰성을 평가하기 위한 방법으로, 패키지 기술과 관련 된 여러 연구에서 많이 사용되고 있다 ${ }^{1-2)}$.

본 연구에서는 낮은 용융점 $\left(139{ }^{\circ} \mathrm{C}\right)$ 으로 인하여 전 자장비의 열충격을 최소화 해주는 장점을 갖고 있는 저 융점 무연 솔더 합금 중 하나인 $\mathrm{Sn}-\mathrm{Bi}$ 계 솔더 페이스 트를 사용하여 젖음성 시험 및 계면반응과 기계적 특성 을 평가하였다. 젖음성 시험은 $\mathrm{ENIG}$ 표면 처리된 기판 과 $\mathrm{Sn}-58 \mathrm{Bi}$ 솔더 페이스트에 할로겐 성분인 chloride 가 함유된 chlrolide-flux 와 chloride가 함유되지 않 은 chloride-free flux를 사용하여 젖음 시간과 젖음력 을 측정하여 젖음 특성을 평가하였다. 접합부의 계면 반응 관찰 및 기계적 특성을 평가하기 위하여 리플로우 공정을 거쳐 솔더 볼을 형성하였고 $125{ }^{\circ} \mathrm{C}$ 의 온도에서 최대 1000 시간동안 열처리를 진행하였다. ENIG 처 리된 기판 위에 솔더 접합부의 기계적 신뢰성의 차이를 전단시험을 통해 분석하였고, $\mathrm{SEM}$ 과 $\mathrm{EDS}$ 를 통해 접 합부 계면반응을 분석하였다.

\section{2. 실험 방법}

본 실험에서 $\mathrm{Sn}-58 \mathrm{Bi}$ 솔더 페이스트가 사용되었으 며, chloride flux와 chloride-free flux의 두 가지 조 건으로 실험이 진행이 되었다. 표면처리 $\mathrm{ENIG}$ 는 $\mathrm{Cu}$ 층 위에 $\mathrm{Ni}-\mathrm{P}$ 층을 $5 \mu \mathrm{m}$, immersion $\mathrm{Au}$ 층을 $0.15 \mu \mathrm{m}$ 무전해 도금 하였다. 도금 후 $10 \%$ 농도의 $\mathrm{H}_{2} \mathrm{SO}_{4}$ 을 이용하여 산세처리를 하였으며 $\mathrm{PCB}$ 기판의 $\mathrm{pad}$ opening size는 $150 \mu \mathrm{m}$ 으로 하였다. 젖음성 시험은 IPC-TM-650 시험방법으로 ENIG 기판을 사용하였고 $\mathrm{Sn}-58 \mathrm{Bi}$ 솔더 페이스트를 $170{ }^{\circ} \mathrm{C}$ 의 온도에서 용융 시 킨 뒤 실시하였다. 또한, 알코올을 이용하여 세척된 ENIG 처리된 PCB (Printed Circuit Board) 기판 위에 stencil printing 방식을 이용하여 $\mathrm{Sn}-58 \mathrm{Bi}$ 솔더 페이스트를 pad 위에 올려서 reflow 공정으로 솔더 볼 을 형성하였다. Fig. 1은 본 연구에서 진행한 stencil printing 공정의 개략도이다. Screen printing 공정을 진행 후 솔더 볼을 형성하기 위해 reflow machine (RF-430-N2, Japan Pulse Laboratory Co. Ltd.) 을 이용하여 최대온도 $170{ }^{\circ} \mathrm{C}$ 에서 10 분 동안 reflow 공정을 진행하였다. Fig. 2는 본 연구에서의 reflow profile을 나타내었다. Reflow 공정을 마친 시편은 de-flux와 $\mathrm{C}_{2} \mathrm{H}_{5} \mathrm{OH}$ 을 이용하여 세척하였다. 그 후 $\mathrm{JEDEC}$ standard ${ }^{3)}$ 에 의거 $125{ }^{\circ} \mathrm{C}$ 의 온도에서 0 , $100,300,500,1000$ 시간 동안 등온 시효 열처리 


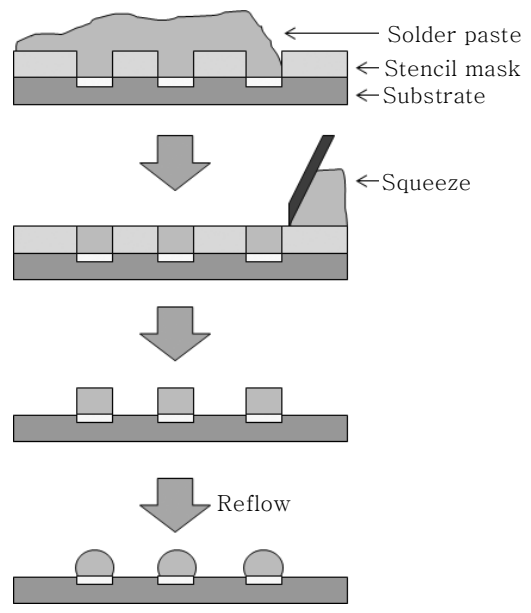

Fig. 1 A schematic view of screen printing process.

후 접합계면의 조직 및 기계적인 접합 강도를 평가하였 다. 첫번째로, $\mathrm{Sn}-58 \mathrm{Bi}$ 솔더의 기계적 접합강도는 전 단시험(PTR-1000, Rhesca)으로 평가하였다. Fig. 3은 전단시험 개략도이다. 전단시험은 JEDEC standard ${ }^{4)}$ 에 따라서 $200 \mu \mathrm{m} / \mathrm{s}$ 의 속도로 $20 \mu \mathrm{m}$ 의 높이에서 각 시편 당 20 회씩 진행하였다. 또한 전단시험 후 $\mathrm{SEM}$ 을 이 용하여 파면으로 파괴 모드(fracture mode)를 관찰하 였다. 마지막으로, 열처리된 시편은 에폭시 수지로 마 운팅 (mounting)한 후 emery paper와 $0.3 \mu \mathrm{m}$ $\mathrm{Al}_{2} \mathrm{O}_{3}$ 파우더를 이용하여 연마(polishing)하였다. 조

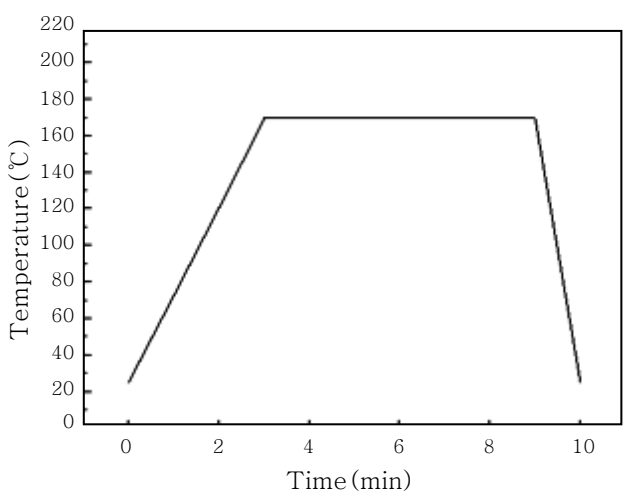

Fig. 2 Reflow temperature profile

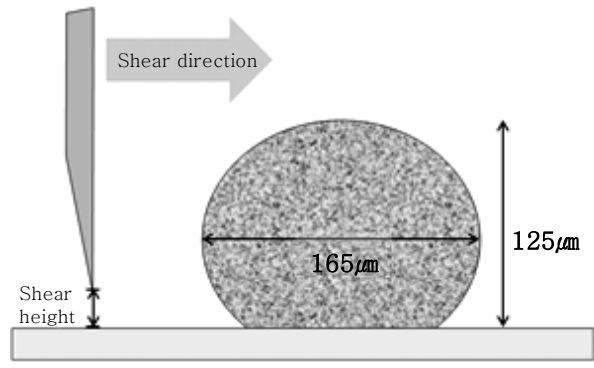

Fig. 3 A schematic view of shear test
직 관찰을 위하여 $\mathrm{Sn}$ 에칭액 $\left(95 \% \quad \mathrm{C}_{2} \mathrm{H}_{5} \mathrm{OH}, 4 \%\right.$ $\left.\mathrm{HNO}_{3}, 1 \% \mathrm{HCl}\right)$ 에 10 초간 에칭 하였고, $\mathrm{SEM}$ (Scanning Electron Microscope)과 EDS (Energy Dispersive Spectroscopy)를 이용하여 조직을 관찰하 고 조성을 분석하였다.

\section{3. 실험 결과 및 고찰}

\section{1 젖음성 시험}

Fig. 4 및 Fig. 5에는 ENIG 기판을 사용하여 chloride flux 및 chloride-free flux가 함유된 $\mathrm{Sn}-58 \mathrm{Bi}$ 솔더 페이스트 젖음력 및 젖음 시간을 젖음성 시험을 통해 나타내었다. 할로겐이 함유되지 않은 chloride-free flux 에 비하여 할로겐이 함유된 chloride flux의 젖음력이 더 높은 것을 알 수 있다. 일반적으로 젖음력은 다음 식으로 나타 낼 수 있고, 그 값으로 상대적인 비교가 가능하므로 간접적인 젖음성의 평가가 가능하다.

$$
F=P \cdot \gamma l f \cdot \cos \theta-B
$$

(F : wetting force, $\mathrm{P}$ : 기판의 둘레, ylf : 솔더flux 간 장력, B : buoyancy force)

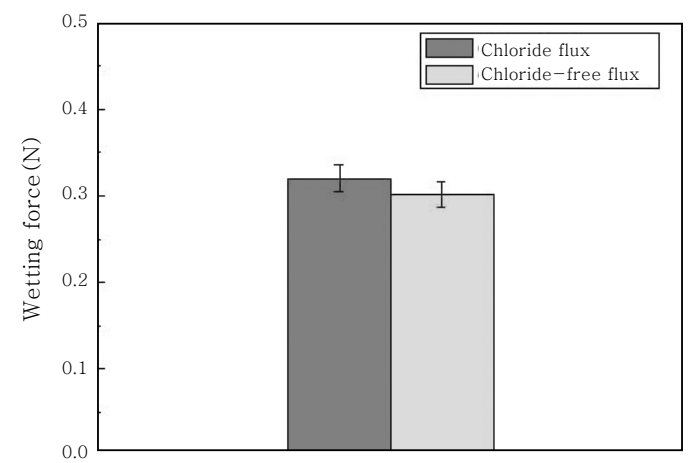

Fig. 4 Wetting force with chloride flux, chloridefree flux

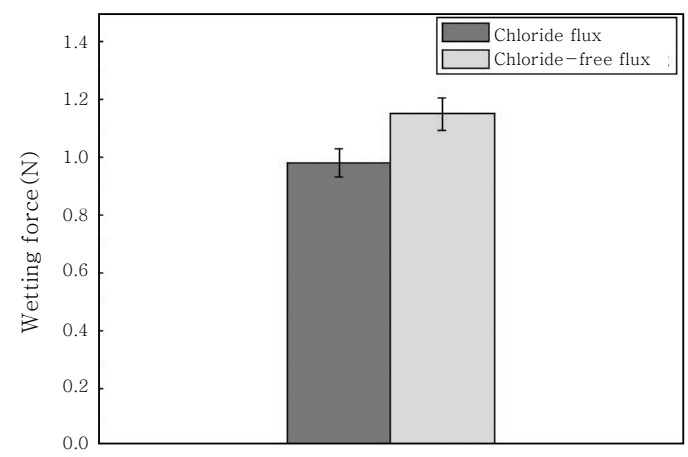

Fig. 5 Wetting time with chloride flux, chloridefree flux 
선행 연구에 의하면 할로겐원소는 온도가 증가할 때 용융 솔더를 활성화하고, 산화물의 형성을 억제하여 솔 더 합금의 젖음성을 향상시키는 것으로 알려져 있다 ${ }^{5)}$. 본 연구 결과에서도 선행 연구결과와 유사하게 chloride flux를 사용했을 때 젖음력은 증가하고 젖음 시간은 감 소하여 우수한 젖음성을 나타내는 것을 알 수 있었다.

\section{2 계면 조직 관찰}

본 연구에 앞서 선행 연구 결과에 의하면 flux 내 chloride 첨가에 따라서 계면 조직 및 기계적 특성에 큰 영향을 미치지 않았다. 따라서 본 연구에서는 chloridefree flux가 첨가된 솔더 페이스트만 사용하여 계면조 직 및 기계적 특성을 조사하였다.

Fig. 6은 $\mathrm{Sn}-\mathrm{Bi}$ 솔더 페이스트를 ENIG 표면 처리 된 기판 위에 솔더링 한 후 등온 시효 열처리 시간에 따른 각각의 접합 계면 $\mathrm{SEM}$ 조직 사진이다. 그림에서 알 수 있듯이 등온 시효 열처리 시간이 증가할수록 $\mathrm{Bi}-$ rich상과 $\mathrm{Sn}$-rich상이 조대화 되는 것을 확인할 수 있었다. 등온 시효 열처리 이전의 reflow만 진행했을 경우 접합계면에는 솔더 접합부 내에는 미세 계면이 관 찰되었으며, $\mathrm{EDS}$ 분석 결과 $\mathrm{Ni} 35.29 \mathrm{wt} \%-\mathrm{Sn}$ $57.48 \mathrm{wt} \%-\mathrm{Bi} \quad 7.24 \mathrm{wt} \%$ 로 나타났다. 이는 $\mathrm{Ni}_{3} \mathrm{Sn}_{4}$ 조성의 금속간 화합물 층인 것으로 사료된다. 300 시간 등온 시효 열처리 후에는 $\mathrm{Ni}_{3} \mathrm{Sn}_{4}$ 금속간 화합물 층 상부 로 다른 계면이 형성되는 것이 관찰되었으며 $\mathrm{EDS}$ 분석 결과 $\mathrm{Ni} 4.00 \mathrm{wt} \%-\mathrm{Sn} 66.05 \mathrm{wt} \%-\mathrm{Au} 13.47 \mathrm{wt} \%-\mathrm{Bi}$ $16.48 \mathrm{wt} \%$ 로 분석이 되었다. 이는 $\mathrm{Sn}-\mathrm{Bi}-\mathrm{Ni}-\mathrm{Au}$ 조 성의 금속간 화합물 층이 생성된 것으로 사료되며, 등 온 시효 열처리 시간의 증가와 더불어 상기 두 종류의 금속간 화합물의 두께는 점차 증가하는 것을 관찰 할 수 있었다. 두 종류의 금속간 화합물이 순차적으로 생 성되고 열처리 시간의 증가에 따라 성장하는 것은 $\mathrm{ENIG}$ 표면 처리된 기판의 $\mathrm{Ni}$ 및 $\mathrm{Au}$ 원자와 솔더의 $\mathrm{Sn}$ 및 $\mathrm{Bi}$ 원자가 상호 확산했기 때문으로 사료된다. 그림과 같이 $\mathrm{Ni}_{3} \mathrm{Sn}_{4}$ 금속간 화합물이 생성되고 그 후

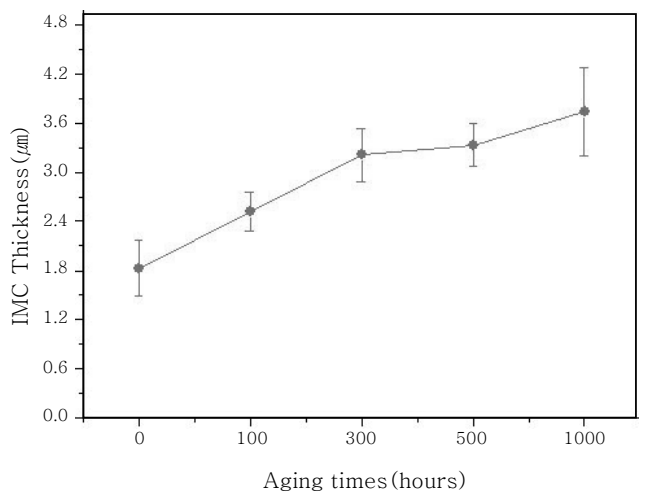

Fig. 7 IMC thickness in the solder joints as a aging time

열처리 시간이 증가할수록 $\mathrm{Sn}-\mathrm{Bi}-\mathrm{Ni}-\mathrm{Au}$ 조성의 화합 물 층이 생성 및 성장하는 현상은 타 연구자의 연구 결 과에서도 확인을 할 수 있다 ${ }^{6-8)}$

Fig. 7 은 금속간 화합물 층 두께를 등온 시효 열처리 시간에 따라 측정한 그래프이다. 금속간 화합물 층의 두께는 열처리 전에는 약 $1.8 \mu \mathrm{m}$ 를 나타내었으며 열처 리 시간이 증가함에 따라 금속간 화합물의 두께는 점차 증가하였으며 1000 시간 등온 시효 처리 이후에는 약 $4 \mu \mathrm{m}$ 두께까지 성장되는 것을 관찰 할 수 있었다.

\section{3 전단시험 결과}

Fig. 8은 등온 시효 열처리 시간에 따른 전단강도 결 과를 나타낸 그래프이다. 최고 전단강도 값은 100 시 간 등온 시효 열처리의 조건에 서 $1.8 \mathrm{~N}$ 의 값을 나타 내었으며, 그 이후에는 점차 감소하여 1000 시간 열처 리 이후에는 $1.5 \mathrm{~N}$ 까지 감소하였다. 일반적으로 접합 계면에 생성된 반응 층의 종류와 그 두께는 솔더 접합 부의 기계적 신뢰성과 깊은 상관 관계가 있고, 임계 두 께 이상의 금속간 화합물 층의 성장은 솔더 접합부의 기계적 강도 값 감소에 큰 영향을 준다고 알려져 있다 9-11). 본 연구 결과에서도 금속간 화합물의 두께가 약 $2.4 \mu \mathrm{m}$ 일 때 가장 높은 전단 강도 값을 나타내었으며, 이후 전단 강도 값이 감소하는 현상은 금속간 화합물의

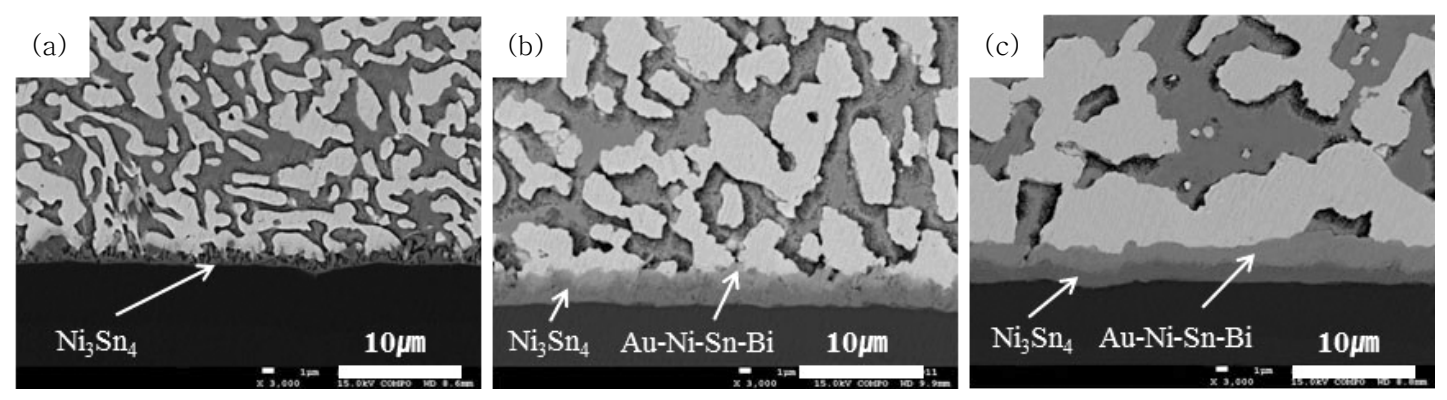

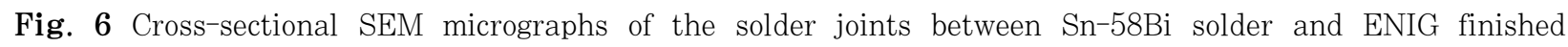
substrate after aging at $125^{\circ} \mathrm{C}$ for; (a) 0 , (b) 300 and (c) 1000 hours 


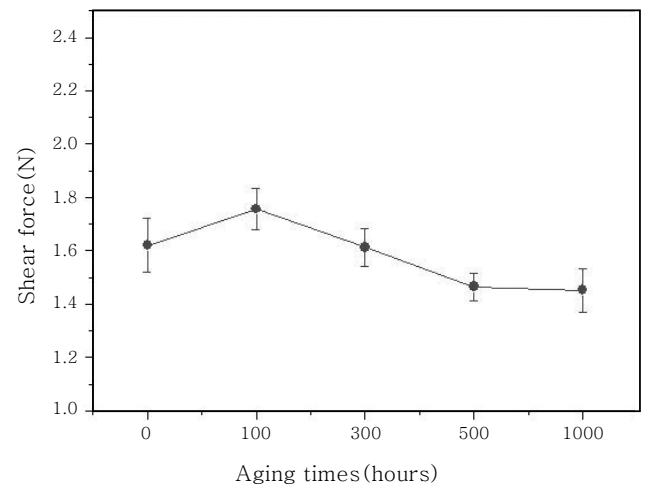

Fig. 8 Shear force of the solder joints as a aging time

성장에 의한 것으로 사료된다. 또한 100 시간 열처리 이후에는 fracture energy 값은 감소하였으며 1000 시간 열처리의 경우에는 약 $0.08 \mathrm{~mJ}$ 을 나타내는 것을 관찰 할 수 있었다. 이러한 현상은 상기 전단 강도 측 정값에서 볼 수 있듯이 적절한 두께의 금속간 화합물이 생성되는 경우에는 전단 강도 값의 증가와 함께 소성 변형 시 충분한 fracture energy를 나타내나 열처리 시간이 증가함에 따라 조대한 금속간 화합물이 생성되 면 금속간 화합물에 의하여 fracture energy가 낮아지 는 현상으로 사료된다.

Fig. 9는 전단 시험 시 연속적으로 측정한 $f-x$ curve 를 보여준다. 1000 시간 등온 시효 열처리 후 전단강 도 값은 열처리 이전의 값에 비하여 다소 감소하는 것 으로 나타났으며 이러한 현상은 상기 언급한 바와 같이 금속간 화합물과 솔더 조직의 조대화에 의한 것으로 사 료된다. Fig. 10 은 전단 강도 시험에서 구한 $\mathrm{f}-\mathrm{x}$ 곡선 의 면적을 이용하여 계산한 fracture energy 값을 나 타낸다. 100 시간 등온시효처리에서 가장 높은 fracture energy 값을 나타내는 현상은 전단강도 측정 결과와 유사한 경향을 나타내었다.

\section{4 파면 관찰 결과}

Fig. 11은 전단시험 후 파단면 분석 결과를 나타낸

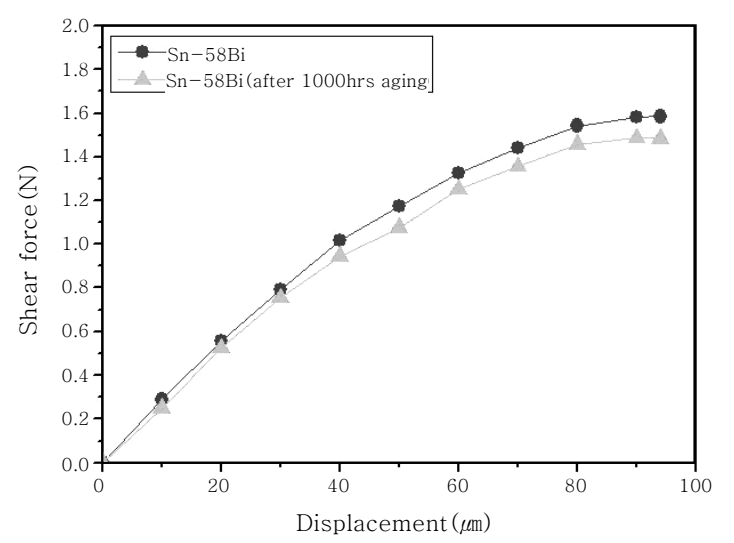

Fig. 9 Force-displacement curves of solder joints

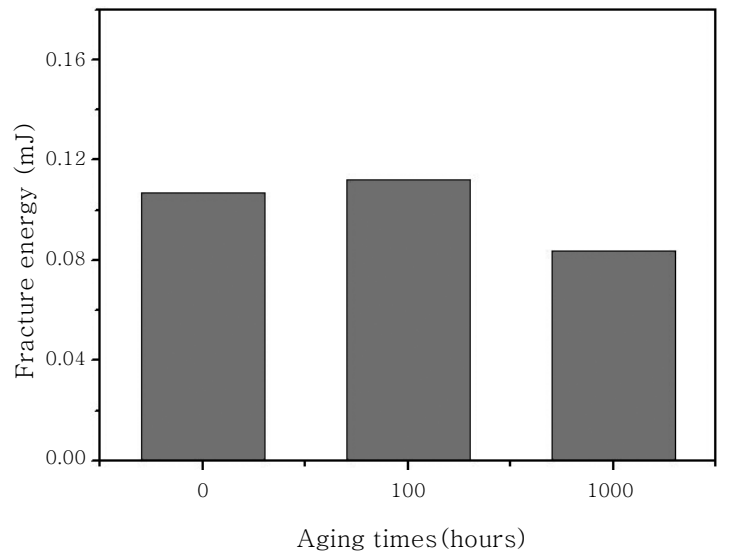

Fig. 10 Fracture energy of solder joints

다. 열처리를 하지 않은 조건의 경우 파단면은 연성 파 단 형태를 나타내었으며 $\mathrm{EDS}$ 분석 결과 $\mathrm{Sn} 40 \mathrm{wt} \%$ $\mathrm{Bi} 60 \mathrm{wt} \%$ 로 나타났다. 이러한 결과를 미루어 볼 때에 열처리를 하지 않은 조건의 경우 전단시험 시 파단은 대부분 솔더 내부에서 파단이 일어난 것으로 사료된다. 열처리 시간이 증가함에 따라 연성 파단 형태에서 취성 파단 형태로 파단면의 형상이 변화하는 것을 관찰 할 수 있었으며 벽개 파단면의 $\mathrm{EDS}$ 분석 결과 $\mathrm{Ni}$ 17.04wt\%-Sn 56.05wt\%-Au 13.52wt\%-Bi 13.39wt\% 로 나타났다. 이러한 $\mathrm{EDS}$ 분석 결과를 고려할 때에 파
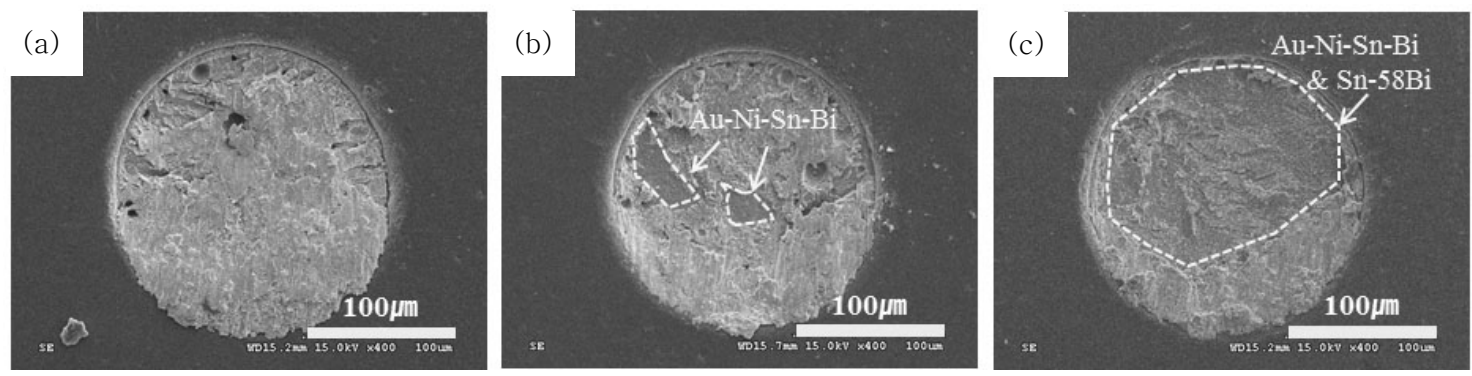

Fig. 11 Fracture surfaces of the solder joints on ENIG finished substrate after aging at $125^{\circ} \mathrm{C}$ for: (a) 0 , (b) 300 and (c) 1000 hours 
단은 $\mathrm{Au}-\mathrm{Ni}-\mathrm{Sn}-\mathrm{Bi}$ 금속간 화합물 층에서 발생한 것으 로 사료된다. 또한 열처리 시간이 증가함에 따라 이러 한 취성 파단의 형태는 점차 증가하는 것으로 관찰 되 었다. 열처리 시간이 증가함에 따라 전단시험 시 파단 이 금속간 화합물에서 발생하는 것은 상기 언급한 바와 같이 열처리 시간이 증가함에 따라 금속간 화합물이 성 장하고 전단시험 시 이러한 충격에 취약한 금속간 화합 물 층으로 전단 응력이 전달되어 나타내는 현상으로 사 료된다 ${ }^{1,13-14)}$.

\section{4. 결 론}

본 연구에서는 대표적인 저온 무연 솔더인 $\mathrm{Sn}-58 \mathrm{Bi}$ 솔더 페이스트를 stencil printing 방법으로 ENIG 표 면 처리된 기판 위에 솔더 볼을 형성하였고 $125{ }^{\circ} \mathrm{C}$ 의 등온 시효 열처리를 진행하면서 접합강도를 평가하였다.

$\mathrm{Sn}-\mathrm{Bi}$ 계 솔더 페이스트의 젖음성은 할로겐원소가 포 함된 chloride flux에서 젖음력은 증가하고 젖음 시간 은 감소하여 전체적으로 젖음성은 향상되었다. 이는 할 로겐 원소가 고온에서 솔더 페이스트의 활성화와 산화 물의 형성을 억제하기 때문으로 사료된다.

접합계면에서는 reflow 초기에 $\mathrm{N}_{\mathrm{i} 3} \mathrm{Sn}_{4}$ 조성의 금속간 화합물 층이 주로 생성되고, 등온 시효 열처리 시간의 증가와 더불어 $\mathrm{Sn}-\mathrm{Bi}-\mathrm{Ni}-\mathrm{Au}$ 조성의 금속간 화합물이 연속적으로 생성, 성장하였다. 금속간 화합물 층은 열처 리 시간이 증가할수록 두꺼워졌다. 전단강도는 약 $1.8 \mathrm{~N}$ 에서 약 $1.5 \mathrm{~N}$ 까지 감소하였고 fracture energy는 $0.10 \mathrm{~mJ}$ 에서 $0.08 \mathrm{~mJ}$ 까지 감소하였다.

등온 시효 열처리 초기에는 주로 연성파괴가 발생하 지만 열처리 시간이 300 시간 이후부터 취성 파괴로 변화되는 것은 솔더 합금에 비하여 상대적으로 취약한 금속간 화합물 층에서 파괴가 시작되기 때문이다.

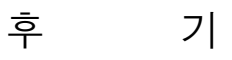

본 연구의 일부는 중소기업청의 기술혁신개발사업 [SA113650, 저온접합 무연솔더합금 개발]의 일환으로 수행하였으며 이에 감사드립니다.

\section{참 고 문 헌}

1. J. W. Kim, S. B. Jung : Experimental and finite element analysis of the shear speed effects on the $\mathrm{Sn}-\mathrm{Ag}$ and $\mathrm{Sn}-\mathrm{Ag}-\mathrm{Cu}$ BGA solder joints, Materials Science and Engineering A, 371 (2004), 267
2. J. H. Ahn, K. S. Kim, Y. C. Lee, Y. Kim and S. B. Jung : Regulation in Shear Test Method for BGA of Flip-chip Packages, Journal of the Microelectronics \& Packaging Society, 17-3 (2010), 1 (in Korean)

3. JEDEC standard, JESD22-A103C, "High temperature storage test", (2004).

4. JEDEC standard, JESD22-B117A, "Solder ball shear", (2006)

5. T. Hisaaki, H. Hideo, T. Toshihiko, Y. Keiichi, Y. Masahiko : Development of Wettability Evaluation Technique Using Contact Angle Measuring Equipment in Soldering, Journal of Japan Institute of Electronics Packaging, 6(6), 488 (2003)

6. B. L. Young, J. G. Duh and G. Y. Jang : Compound Formation for Electroplated $\mathrm{Ni}$ and Electroless $\mathrm{Ni}$ in the Under Bump Metallurgy with Sn-58Bi Solder during Aging, Journal of Electronics Matericals, 32(2003), 12

7. C. C. Chi, L. C. Tsao, C. W. Tsao and T. H. Chuang : Intermetallic Reactions in reflowed and Aged Sn-58Bi BGA Packages with $\mathrm{Au} / \mathrm{Ni} / \mathrm{Cu}$ Pads, Journal of Materials Engineering and Performance, 17 (2008), 134

8. M. G. Cho, H. M. Lee, S. W. Booh and T. G. Kim : Interfacial Reacion between $42 \mathrm{Sn}-58 \mathrm{Bi}$ Solder and Electroless $\mathrm{Ni}-\mathrm{P} / \mathrm{Immersion} \mathrm{Au} \mathrm{Ubm}$ during Aging, Journal of Electronic Materials, 12 (2005), 95

9. M. C. Yew, C. Y. Chou, K. N. Chiang : Reliability Assessment for Solders with a Stress Buffer Layer using Ball Shear Strength Test and Board-level Finite Element Analysis, Microelectronics Reliability 47, 9-11 (2007), 1658

10. J. W. Kim, S. B. Jung, Spring Conference of KWS, Samcheok, 18, Journal of KWS, (2006) (in Korean)

11. J. W. Kim, S. B. Jung : Failure mechanism of $\mathrm{Pb}$-bearing and $\mathrm{Pb}$-free solder joints under high-speed shear loading, Metals and Materials International, 16-1 (2010), 7

12. S. S. Ha, J. K. Jang, S. O. Ha, J. W. Kim, J. W. Yoon, B. W. Kim, S. K. Park, S. B. Jung : Mechanical Property Evaluation of $\mathrm{Sn}-3.0 \mathrm{~A}-0.5 \mathrm{Cu}$ BGA Solder Joints Using High-Speed Ball Shear Test, Journal of Electronic Materials 38-12 (2009), 2489

13. J. M. Koo, S. B. Jung : Effect of displacement rate on ball shear properties for $\mathrm{Sn}-37 \mathrm{~Pb}$ and $\mathrm{Sn}-3.5 \mathrm{Ag}$ BGA solder joints during isothermal aging, Microelectronics Reliability 47-12 (2007), 2169

14. X. J. Wang, Z. G. Wang, J. K. Shang, proc. International Conference on Electronic Packaging Technology \& High Density Packaging (ICEPTHDP), Shanghai, 1-4, IEEE Components, Packaging and Manufacturing Technology Society (CPMT) (2008) 